\title{
HISTORISITAS, SETTING SOSIAL, POLITIK, DAN KARAKTER HUKUM ISLAM DI KALIMANTAN SELATAN
}

\author{
Zainal Muttaqin \\ UIN Antasari Banjarmasin \\ zainalmuttaqin@uin-antasari.ac.id \\ Diterima 15-07-2020 | Direview 22-09-2020 | Diterbitkan 18-12-2020
}

\begin{abstract}
:
Since Islam was accepted as the official religion of the Banjar kingdom, since then Islamic law also influenced the system of social norms and state administration. In its history, the existence of Islamic law has experienced ups and downs that are strongly influenced by social and political factors that occur in the South Kalimantan region. The role of the ulama, especially Sheikh Muhammad Arsyad al-Banjari along with his descendants contributed greatly in shaping the contextual and localistic character of Islamic law. Which in some cases was different from what had been formulated by earlier jurists.
\end{abstract}

Keywords: Localistic, UUSA, Al-Banjari, Qadi

\begin{abstract}
Abstrak:
Sejak Islam diterima sebagai agama resmi kerajaan Banjar, maka hukum Islam juga mempengaruhi sistem norma sosial dan ketatanegaraan. Dalam sejarahnya, eksistensi syariat Islam mengalami pasang surut yang sangat dipengaruhi oleh faktor sosial dan politik yang terjadi di wilayah Kalimantan Selatan. Peran ulama khususnya Syekh Muhammad Arsyad al-Banjari beserta keturunannya memberikan andil yang besar dalam membentuk karakter kontekstual dan lokalistik hukum Islam. Yang dalam beberapa kasus berbeda dengan apa yang telah dirumuskan oleh ahli hukum sebelumnya.
\end{abstract}

Kata Kunci: Lokalitas, UUSA, Al-Banjari, Adi

\section{Pendahuluan}

Secara geografis wilayah yang disebut dengan Kalimantan Selatan terletak di tenggara wilayah Kalimantan dengan luas wilayah yang relatif kecil 
dibandingkan dengan wilayah provinsi lain di Pulau Kalimantan. Luas Kalimantan Selatan adalah sekitar $37.530,52 \mathrm{~km}^{2}$ yang terdiri dari sebelas Kabupaten dan dua kota dengan tingkat kepadatan penduduk sekitar 3,7 juta jiwa. ${ }^{1}$ Meskipun demikian, wilayah ini mempunyai sejarah panjang dan peran yang penting dalam sejarah Indonesia keseluruhan. Tercatat bahwa di wilayah ini pernah ada tiga kerajaan besar yang berpengaruh di Pulau Kalimantan, ${ }^{2}$ bahkan di daerah ini pula letak ibukota provinsi Kalimantan sebelum akhirnya dimekarkan menjadi beberapa provinsi.

Ketika kita berbicara tentang provinsi ini, maka diskursusnya tidak akan lepas dari pembicaraan tentang komunitas yang mendiami wilayah tersebut dengan setiap aspek dinamikanya. Sudah semenjak lama wilayah ini didiami oleh penduduk yang multi etnik. Namun apabila ditarik ke belakang, wilayah ini pada awalnya didiami oleh sekelompok etnik tertentu yang diidentifikasi sebagai orang bukit, yang merupakan salah satu dari sub suku Dayak sebagai penduduk asli Pulau Kalimantan. Terkait dengan Islam, maka pembicaraan tentang penduduk wilayah ini akan menarik apabila dihubungkan dengan suku Banjar yang dikenal sampai sekarang ini sebagai penduduk yang identik dengan wilayah ini. Ini bukan berarti menafikan peran suku lain yang berdiam di wilyah ini, namun memfokuskan perhatian terhadap peran urang Banjar juga tidaklah salah dengan melihat keidentikkan wilayah ini dengan urang Banjar, sehingga biasanya ketika menyebut urang Banjar, baik di mana pun berada, dipastikan bahwa pikiran kita akan menuju kepada sebuah komunitas yang berasal dari wilayah Kalimantan Selatan. Di samping itu pula, mendiskusikan dinamika hukum Islam semenjak berdirinya Kesultanan Banjar sampai dengan masa sekarang ini tentu akan memerlukan pembahasan yang panjang baik dari aspek kesejarahannya maupun aspek wilayah dan para penduduknya.

Pertanyaan yang menarik untuk didiskusikan adalah bagaimana urang Banjar menjadikan Islam sebagai salah satu unsur pembentukan identitas mereka. Urang Banjar pada umumnya dikenal sebagai pemeluk agama Islam, dan bahkan apabila ada orang dayak (meratus) beralih ke agama Islam, maka dianggap tidak hanya terjadi sebuah konversi keyakinan saja, namun juga dianggap terjadi sebuah konversi suku sehingga orang Dayak muslim tidak lagi

\footnotetext{
1 "Demografis Kalimantan Selatan," November $\quad$ 9, 2019, https://id.wikipedia.org/wiki/Kalimantan_Selatan.

2 Sunarningsih Sunarningsih, "Situs Jangkung Dan Komunitas Maanyan," Naditira Widya, 2, 0 (Oktober 2016).
} 
disebut dengan Dayak, namun Banjar. ${ }^{3}$ Dijadikannya Islam sebagai sebuah identitas etnis, ternyata juga berimpilkasi terhadap pengamalan keagamaan mereka, termasuk pengamalan hukum Islam. Bagaimana hukum Islam sebagai bagian dari ajaran agama berbaur dengan tradisi lokal (local wisdom) yang sudah ada sehingga membentuk karakter tersendiri dalam implementasi hukum tersebut

\section{Metode}

Tulisan ini dimaksudkan untuk menggambarkan tentang sejarah perkembangan hukum Islam di wilayah Kalimantan Selatan semenjak Islam diterima sebagai agama resmi di wilayah ini sampai sekarang. Oleh karena itu maka sasaran atau objek dari tulisan ini adalah tentang sejarah sosial, politik, dan karakter hukum Islam di wilayah Kalimantan Selatan. Untuk memperoleh data yang diinginkan, maka penulis membaca dan menelaah beberapa referensi yang dapat dijadikan sebagai sumber data yang kemudian dianalisa dengan pendekatan deskriptif kualitatif

\section{Sejarah (Suku) Banjar dan Identitas Keislaman}

Wilayah Kalimantan Selatan sekarang ini, dalam bahasa keseharian masyarakatnya sering disebut pula dengan nama banua Banjar, dan masyarakat aslinya sering disebut dengan masyarakat Banjar. Untuk merujuk kepada setiap individunya maka disebut dengan urang Banjar. Penyebutan tersebut dimaksudkan untuk menunjukkan identitas asal seseorang yang meliputi asal keturunannya (silsilah), dilahirkan, hidup dan bertempat tinggal di wilayah ini. Dari hal ini, walaupun seseorang dilahirkan, hidup dan bertempat tinggal di banua Banjar, namun secara keturunan bukanlah berasal dari asli daerah ini, maka tidak bisa disebut dengan urang Banjar. Namun sebaliknya walaupun dilahirkan, hidup dan bertempat tinggal di luar wilayah Banjar, namun secara keturunan berasal dari banua Banjar, maka orang tersebut disebut sebagai keturunan urang Banjar. Istilah terakhir ini menurut Arif Rahman Hakim tidak bisa dikatakan sebagai urang Banjar, karena tidak dilahirkan di wilayah banua Banjar, walaupun mempunyai garis keturunan Banjar, dan kalimat tersebut lebih tepat untuk digunakan, sebagai garis pembeda yang tegas sebagai urang Banjar asli dan urang Banjar keturunan. ${ }^{4}$ Terlepas dari itu, ada sebuah kata yang dapat

\footnotetext{
3 Gusti Muzainah, Asas Kemanfaatan Tentang Kedudukan Perempuan Dalam Hukum Waris Adat Msyarakat Banjar (Yogyakarta: Pustaka Akademika, 2016).

4 Arif Rahman Hakim, "Urang Banjar Asli, Urang Banjar Keturunan Dan Jarwo," Idr UIN Antasari Banjarmasin, n.d., https://idr.uin-antasari.ac.id/6268/.
} 
digunakan untuk menggabungkan urang Banjar dan Banjar keturunan sebagai sebuah entititas etnik yaitu dengan menambahkan kata bububan sehingga menjadi kalimat bububan Banjar yang menyatukan urang Banjar dan Banjar keturunan sebagai satu identitas etnik. Oleh karena itulah, siapa pun yang berasal dari keturunan Banjar dan tersebar di wilayah mana pun, mereka secara emosional akan merasa sebagai bagian dari urang Banjar itu sendiri.

Pertanyaan yang sering muncul dalam benak kita adalah dari mana kata Banjar itu berasal dan bagaimana kata tersebut digunakan untuk menyebut sebuah etnik di wilayah Kalimantan Selatan. Untuk menjawab pertanyaan tersebut, salah satu referensi yang sering dikutip oleh para penulis untuk menjelaskan hal tersebut adalah Hikayat Banjar yang ditulis oleh J.J. Ras, sebagaimana yang dikutip oleh Gusti Muzainah, disebutkan bahwa istilah "Banjar" berasal dari kata "Banjarmasih" yang merujuk kepada sebuah wilayah yang pada saat itu dipimpin oleh seorang patih yang bernama Patih Masih. Nama Patih Masih sendiri adalah sebutan untuk Patih oloh Matih yang berarti kepala suatu etnis tertentu. Sedangkan kata Banjar diartikan sebagai suatu kampung atau pemukiman yang dibangun dan terletak di atas air sepanjang sungai secara berderet-deret. ${ }^{5}$ Dengan demikian, kata Banjar pada awalnya diidentikkan dengan kata Banjarmasih yang diartikan sebagai sebuah kampung atau pemukiman yang dibangun dengan berderet-deret di atas air dan dipimpin oleh seorang pembesar Melayu yang dinamakan patih Masih, sehingga wilayah tersebut bernama Banjarmasih. Kata inilah yang kemudian hari menurut Idwar Saleh, melekat untuk menunjukkan wilayah yang berada di Kalimantan Selatan dan menyebutnya dengan istilah nama Negeri Banjar, Kota Banjar, Raja Banjar, Urang Banjar dan Tanah Banjar. ${ }^{6}$ Dengan demikian, nama Banjar sesungguhnya sudah ada sebelum berdirinya kerajaan Islam pertama di daerah ini yaitu Kerajaan Banjar yang berkembang dengan pesat menjadi sebuah kerajaan besar dengan wilayah kekuasaanya mencakup wilayah Kalimantan Selatan sekarang, sebagian Kalimantan Timur dan Tengah.

Asal usul urang Banjar sendiri sampai saat ini masih menjadi sebuah pertanyaan besar. Hal ini disebabkan tidak adanya sumber sejarah yang valid dan otoritatif. Selama ini bahasan-bahasan yang muncul untuk mendiskripsikan tentang asal usul suku Banjar berangkat dari asumsi-asumsi yang berasal dari

\footnotetext{
${ }^{5}$ Muzainah, Asas Kemanfaatan Tentang Kedudukan Perempuan Dalam Hukum Waris Adat Msyarakat Banjar.

${ }^{6}$ Idwar Saleh, Sejarah Singkat Menegenai Bangkit Dan Berkembangnya Kota Banjarmasin Serta Wilayah Sekitarannya Sampai Tabun 1950 (Banjarmasin, 1975).
} 
sumber-sumber yang terbatas, dan bahkan tidak jarang bersifat kontroversial. Menurut Wardani, ada tiga tesis yang dapat diajukan untuk menjelaskan hal ini, dan semuanya masih terkait dengan pendekatan primordialisme yang melihat urang Banjar sebagai sebuah percampuran antar suku, bahasa, agama, budaya dan organisasi sosial. Ketiga tesis tersebut yaitu pertama seperti yang diungkapkan oleh Alpani Daud dengan mengemukakan tiga asumsi yaitu pertama bahwa suku Banjar berasal dari suku Melayu Sumatera yang berimigrasi ke wilayah selatan bagian Kalimatan pada ribuan tahun yang lalu dan menyebar ke wilayah lembah Sungai Nagara dan Sungai Barito serta wilayah lain yang masuk dalam wilayah Banjar saat ini. Asumsi kedua bahwa suku Dayak Meratus yang sekarang mendiami wilayah pegunungan Meratus merupakan suku Melayu pertama yang datang ke wilayah ini, yang kemudian terdesak oleh kedatangan suku Melayu yang kedua. Asumsi ketiga bahwa, terjadi perbauran antara suku Melayu pertama dengan suku Melayu yang datang belakangan dan pada akhirnya melebur menjadi sebuah etnik yang disebut dengan suku Banjar. ${ }^{7}$

Tesis yang kedua adalah bahwa pada awalnya terjadi sebuah migrasi besar-besaran yang terjadi sekitar tahun 3000-1500 SM yang berasal dari wilyah Cina Selatan dan menyebar ke wilayah Asia bagian Tenggara. Di antara imigran tersebut terdapat kelompok yang memasuki Pulau Kalimantan yang disebut dengan kelompok Negrid dan Weddid yang kemudian disebut dengan Proto Melayu. Setelah itu datang lagi gelombang kedua imigran besar yang diebut dengan Deutro Melayu dan mendiami wilyah pantai Kalimantan. Pada dasarnya keduanya berasal dari suku yang sama, namun yang membedakan adalah terjadinya proses pembauran dengan beragam suku yang sebelumnya sudah ada di Indonesia. Dari situ maka dikenal ada istilah Dayak dan Haloq (suku yang menganut agama Islam). Tesis ketiga adalah sebagaimana yang dikutip oleh Wardani dari Idwar Saleh yang menjelaskan bahwa suku Banjar bukanlah sebuah kasatuan etnik tertentu, namun merupakan sebuah perpaduan antar suku dengan suku Dayak, terutama Maanyan, Ngaju dan Meratus atau Bukit sebagai unsur utamanya dan suku-suku lain seperti Melayu, Jawa yang berpadu membentuk suatu kesatuan budaya dengan ciri utama agama Islam, bahasa dan budaya Banjar. Perpaduan ini terjadi dengan berdirinya kerajaan Islam Banjar, sehingga saat itu dikenal hanya ada tiga kelompok besar Banjar yaitu Banjar

\footnotetext{
7 Wardani, "Madam Ka Banua Urang Beberapa Catatan Awal Tentang Migrasi Suku Banjar, Proses Dan Peyebarannya," Jurnal Kebudayaan Kandil V, no. 14 (Oktober 2007).
} 
Kuala, Banjar Batang Banyu dan Banjar Pahuluan. ${ }^{8}$ Dari hal ini, Idwar Saleh menilai bahwa unsur utama dari pembentuk suku Banjar adalah suku Dayak. Hal ini sebagaimana yang dijelaskan oleh beliau lebih lanjut sebagaimana yang dikutip oleh Wardani bahwa Banjar Kuala yang membentang dari kota Banjarmasin sampai dengan Martapura dan sekitarnya berasal dari kesatuan etnik Ngaju. Adapun Banjar Batang Banyu adalah mereka yang bermukim di aliran sungai tabalong sampai ke hilirnya yang terletak di sungai barito berasal dari etnik Maanyan. Sedangkan Banjar Pahuluan adalah mereka yang bermukim di sekitar pegunungan Meratus yang terletak dari dari Tanjung sampai ke wilayah Pelaihari berasal dari Dayak Bukit.' Senada dengan itu, Gazali Usman menyebutkan bahwa suku Banjar itu bukan menunjukkan kepada etnik atau suku, namun merupakan perpaduan beberapa suku atau kelompok sehingga menjadi suatu kelompok. ${ }^{10}$

Terlepas dari perbedaan perspektif tentang asal mula urang Banjar, satu hal yang menjadi karekteristik utama urang Banjar adalah bahwa mereka pada umumnya pemeluk agama Islam. ${ }^{11}$ Dalam sejarahnya, Islamisasi daerah ini secara formal tidak lepas dari persoalan politik dan kekuasaan. ${ }^{12}$ Sebagaimana yang telah banyak ditulis oleh para sejarahwan bahwa awal mula Islam masuk ke wilayah ini dipicu oleh adanya peperangan "bapadaan" antara Pangeran Samudera (nama Sultan Suriansyah sebelum memeluk agama Islam) dengan pamannya yang bernama Pangeran Tumenggung dalam memperebutkan tahta Kerajaan Daha yang semestinya adalah hak mutlak Pangeran Samudera. Untuk mengalahkan pamannya, Pangeran Samudera meminta bantuan Demak untuk mengirimkan pasukan, karena kekuatan yang dimiliki oleh Pangeran Samudera diperhitungkan tidak sebesar dan sekuat pasukan pamannya. Untuk memenuhi bantuan tersebut, Kerajaan Demak mensyaratkan adanya sebuah perjanjian yaitu konversi kepercayaan dan keyakinan asal Pangeran Samudera dan rakyat Banjar ke Islam, apabila Pangeran Samudera dapat memenangkan peperangan tersebut. Setelah disepakati, maka Kerajaan Demak mengirimkan pasukan sebanyak 10.000. Setelah terjadi peperangan dalam jangka waktu yang lama, dan dilanjutkan

\footnotetext{
${ }^{8}$ Wardani.

${ }^{9}$ Wardani.

${ }^{10}$ Gazali Usman, Urang Banjar Dalam Sejarah (Banjarmasin: Lambung Mangkurat University Press, 1989).

11 Alfani Daud, Islam Dan Masyarakat Banjar Diskripsi Dan Analisa Kebudayaan Banjar (Jakarta: Raja Grafindo Persada, 1997).

${ }^{12}$ Daud.
} 
dengan kesepakatan untuk perang tanding antara Pangeran Samudera dengan Pangeran Temenggung, maka sebelum pertarungan itu terjadi, Pangeran Temenggung mengakui kesalahaannya dan menyerah kalah. Setelah Pangeran Samudera dianggap memenangkan peperangan tersebut, maka sesuai dengan perjanjian, Pangeran Samudera menjadi seorang muslim dan mengganti namanya dengan Pangeran Suriansyah. Ini kemudian diikuti oleh para pembesar, keluarga dan rakyat Banjar. ${ }^{13}$

Peran Sultan Suriansyah sebagai raja pertama kesultanan Banjar sangat besar dalam upaya islamisasi dan mengupayakan internalisasi agama ke dalam sendi kehidupan kerajaan. Ketika menjadi Sultan, beliau melakukan perubahan struktur birokrasi dengan menanggalkan semua struktur kerajaan terdahulu yang bercorak Hindu. Dalam struktur birokrasi baru tersebut dibuat aturan birokrasi hukum yang berbeda antara masalah keagamaan dengan masalah hukum sekuler yang disebut dengan Dirgama. Dalam masalah hukum Islam, anggota musyawarahnya adalah Mangkubumi, Dipati, Jaksa, khalifah dan Penghulu yang menjadi pemimpin musyawarah. Sedangkan dalam hukum dirgama, anggota musyawarahnya terdiri dari Raja, Mangkubumi, Dipati dan Jaksa yang menjadi pemimpin rapatnya. Namun dalam struktur tersebut kewenangan seorang Penghulu lebih besar dibandingkan kewenangan Jaksa, karena penghulu mengurusi persolan agama. ${ }^{14}$ Dengan demikian, Islam menjadi agama resmi kerajaan, dan menjadi salah satu identitas bagi rakyat kerajaan itu. Bahkan Islam mampu untuk menjadi pembentuk unsur identitas budaya baru, yaitu budaya Banjar yang diwarnai dengan identitas lokal yang masih dipertahankan. ${ }^{15}$

\section{Hukum Islam di Masa Kerajaan Banjar}

Semenjak Islam dianut oleh masyarakat kerajaan Banjar, maka terjadi perubahan kehidupan masyarakat yang pada awalnya didasarkan kepada ajaran atau keyakinan lama kepada keyakinan yang baru pada pelbagai segi kehidupan masyarakat termasuk dalam konteks hukum. Dalam hal ini peran Sultan dan Ulama memiliki kontribusi yang besar dalam pemberlakuan hukum Islam terhadap rakyat Banjar. Sultan berperan dalam perubahan struktur birokrasi kerajaan dengan diakomodirnya jabatan urusan hukum Islam. Terkait dengan

\footnotetext{
${ }^{13}$ J.J Ras, Hikayat Banjar: A Study in Malay Historiography (The Hague: Martius Najhoff, n.d.).

${ }^{14}$ Muhammad Azmi, "Islam Di Kalimantan Pada Abad Ke-15 Sampai Abad Ke -17," Yupa: Historical Studies Journal, 1, 1 (n.d.).

15 Yusliani Noor, "Sejarah Perkembangan Islam Di Banjarmasin Dan Peran Kesultanan Banjar (Abad XV-XIX)," Al-Banjari, 1, 11 (2012).
} 
sejauhmana hukum Islam diterapkan saat itu, tidak ada informasi yang lengkap bisa didapatkan karena kurangnya referensi historis yang dapat digunakan untuk menjelaskan hal tersebut. ${ }^{16}$ Namun apabila melihat kepada diakomodirnya jabatan keagamaan di awal kesultanan Banjar, patut untuk diduga bahwa hukum Islam sudah menjadi hukum yang berlaku di kerajaan, yang tidak hanya berkaitan dengan persoalan hukum keperdataan (al-Ahwal alSyakbsiyyah) saja namun juga menyangkut hukum pidana (jinayah). Menurut Warkum Sumitro sebagaimana yang dikutip oleh Syifa dan Nabila Saifin Nuha Nurul Haq bahwa tercatat dalam sejarah Banjar ada diterapkan hukum bunuh bagi orang yang murtad, hukum potong tangan bagi pencuri, dan hukum dera (cambuk) bagi pezina. Sementara ini penulis belum mendapatkan referensi pembanding tentang hal ini, namun keberadaan lembaga mufti dan qadhi juga semakin menegaskan bahwa hukum Islam berlaku di kerajaan saat itu, dan kemungkinan bahwa hukum jinayat juga menjadi hukum yang berlaku saat itu. Ada sebuah adagium yang dikenal di kerajaan Banjar untuk memperkuat hal ini yaitu "Patih Baraja'an Dika, Andhika badayan Sara"yang artinya "Saya tunduk pada perintah Tuanku, karena Tuanku berbukumkan bukum syara". ${ }^{17}$ Penyebutan Andhika badayan Sara mengindikasikan bahwa syariat Islam yang diterapkan tidak hanya mengenai keperdataan saja namun juga hukum pidana Islam.

Perkembangan hukum Islam di tanah Banjar mengalamai perkembangan yang signifikan dibandingkan sebelumnya yang dimulai pada masa masa Sultan Tahmidullah II seiring dengan kedatangan Syekh Muhammamd Arsyad al-Banjari (selanjutnya dalam tulisan ini cukup disebut dengan al-Banjari) dari Timur Tengah. Perannya tersebut semakain konkrit dengan adanya Kitab Sabil al-Muhtadin yang ditulis berdasarkan permintaan Sultan. Di samping itu pula, al-Banjari mengusulkan dibentuknya lembaga peradilan dengan nama Mahkamah Syar'iyyah dengan jabatan mufti sebagai ketua dan didampingi oleh qadi yang bertugas menjalankan hukum dan mengatur jalannya peradilan. ${ }^{18}$ Keberadaan lembaga Mahkamah Syar'iyyah menggantikan kedudukan lembaga hukum dan keagamaan sebelumnya, yaitu penghulu, khatib dan khalifah. Tidak ada catatan yang jelas untuk menunjukkan

\footnotetext{
16 Mujiburrrahman Mujiburrahman, Allfisyah Alfisyah, and Ahmad Syadzali, "Badingsanak Banjar Dayak Indentitas Agama Dan Ekonomi Etnisitas Di Kalimantan Selatan," Riset Kaloborasi Program Knowlegde Based Pluralism CRCS UGM, n.d., http://eprints.ulm.ac.id/219/2/14\%20Badingsanak\%20Banjar\%20Dayak.pdf.

${ }_{17}$ Syifa and Nabila Saifin Nuha Nurul Haq, "Politik Hukum Islam Era Kesultanan," Jurnal Reflektika 13, no. 1 (June 2017).

${ }^{18}$ Syifa and Nurul Haq.
} 
adanya alasan perombakan tersebut, namun yang jelas bahwa sejak di awal Kesultanan Banjar bendiri, penyerahan urusan peradilan keagamaan diserahkan kepada para ulama, sedangkan urusan politik kerajaan dan ekonomi menjadi domain wilayah para birokrat kesultanan.

Hukum Islam semakin mendapatkan kedudukannya di tengah-tengah kerajaan dan masyarakat di saat kerajaan Banjar di bawah kekuasaan Sultan Adam al-Wasik Billah yang memerintah tahun 1825-1857 M. Di Masa itulah tepatnya pada athun 1835 M diterbitkannya Undang-Undang Sultan Adam yang sering disingkat dengan UUSA, yang sangat jelas didasarkan kepada hukum Islam. ${ }^{19}$ Lahirnya Undang-Undang ini pada satu sisi memperlihatkan perhatian yang besar dari penguasa untuk menjadikan hukum Islam sebagai suatu hukum positif di Kesultanan Banjar yang semakin menegaskan bagaimana Islam menjadi spirit dalam mengatur kehidupan masyarakat. Namun apabila dilihat dari sisi sosial politik saat itu, bisa saja melahirkan sebuah perspektif yang berbeda dengan memandang lahirnya Undang-Undang ini. M. Faqih de Ridha dalam tulisannya memberikan analisa yang bisa menjelaskan tentang lahirnya Undang-Undang ini dari perspektif sosial politik tersebut. Di masa Sultan Adam, penjajah Belanda sudah menunjukkan kekuasaannya. Hal ini berimbas terhadap kekuatan politik sudah tidak berada di tangan Sultan lagi, namun Banjar sendiri masih tetap diakui sebagai sebuah kerajaan. Oleh karena itulah, Sultan dituntut untuk mampu menterjemahkan pengakuan ini menjadi "seperti" kekuasaan politik. Strateginya adalah melalui pemberlakuan hukum. Sebab, secara teoritis, hukum merupakan upaya menjaga, menata sekaligus mengontrol jalannya kehidupan sosial. Peluang untuk melakukan hal ini tersedia dan dengan berlakunya UUSA yang berarti bahwa kekuasaan Sultan Adam belumlah habis. ${ }^{20}$

Lebih lanjut menurut Faqih, ada beberapa kebijakan Sultan Adam yang dapat dibaca sebagai sebuah usaha untuk menunjukkan masih adanya eksistensi kekuasaan sultan yaitu pertama, berubahnya peran qadi menjadi hakim. Sebelum kekuasaan Sultan Adam, qadi adalah jabatan tertinggi yang menangani persoalan-persoalan agama. Namun di masa kekuasaanya fungsi qadi diambil alih langsung oleh Sultan. Untuk persoalan-persoalan agama secara umum diserahkan kepada hakim saja. Hal ini menjadi sebuah indikator bahwa ketika kekuasaan politik sudah memudar, penguasa bisa menggunakan

\footnotetext{
${ }^{19}$ Syifa and Nurul Haq.

20 . Faqih de Ridha, "Potert Lain Perjalanan Hukum Di Kerajaan Banjar," Al-Banjari 12, no. 1 (January 2013).
} 
sumber kekuatan yang lain untuk tetap berkuasa yaitu kekuasaan agama. Hal ini dimungkinkan karena secara pribadi Sultan Adam adalah sosok yang dikenal terdidik dan cerdas, memiliki rekam jejak politik yang relatif bersih serta dekat dengan para ulama. Di samping pergeseran peran tersebut, Sultan Adam juga merapikan perangkat peradilan. Ada 10 pasal yang memuat peradilan dan hukum acara dan bidang ini merupakan peraturan terbanyak dalam UUSA. Hal ini semakin memperjelas upaya menjaga eksistensi kekuasaan Banjar melalui ranah hukum. Dengan kata lain, merapikan hukum bisa berarti merapikan kekuasaan. ${ }^{21}$

Kedua, dalam UUSA terdapat ada 6 pasal yang mengatur tentang persoalan tanah. Secara normatif pengaturan tersebut tidak berbenturan dengan wacana fiqh. Dalam sebuah kekuasaan tradisional seperti Kerajaan Banjar, semua tanah yang yang berada di wilayah kekuasaan Banjar adalah milik Kerajaan Banjar kecuali jika ada izin penguasa untuk mengelolanya. UUSA memulai pembahasan tanah pada pasal 17. Di dalamnya dijelaskan bahwa siapa saja yang memiliki tanah yang berada dalam proses muamalat harus dicatat dalam sebuah prosedur administratif kerajaan. Padahal, di satu sisi, kita tahu bahwa pemilik tanah pada masa itu hanya elit kerajaan, bangsawan dan elit masyarakat. Ada kemungkinan peraturan ini berkaitan dengan penguasaan tanah yang berkurang sejak kedatangan Belanda. Penguasaan atas tanah selama ada di tangan para bangsawan kerajaan memiliki masalah dan oleh karena itu perlu diatur secara formal. Semua tanah yang tersisa dari kekuasaan Banjar memerlukan pendataan dan penghitungan kembali untuk memastikan wilayahwilayah mana saja yang masih tetap di bawah kekuasaan Banjar. Dari aspek fikih terutama maslahah, pasal-pasal tersebut tidak bertentangan, namun menceremati lahirnya kebijakan tersebut dengan perspektif sosial politik saat itu juga, tidaklah salah. ${ }^{22}$

Terlepas dari perspektif sosial politik dari lahirnya UUSA, penulis memahami bahwa kelahiran undang-undang tersebut menunjukkan kuatnya pengaruh Islam terhadap kehidupan sosial masayrakat saat itu sehingga masyarakat Banjar pada akhirnya dikenal sebagai masyarakat yang kental dengan tradisi keislaman. Dalam konteks ini, posisi ulama mendapatkan kedudukan yang penting, sehingga melahirkan sebuah kepatuhan sosial baik secara formal maupun non formal. Hal ini juga menjadi sebuah petunjuk bahwa dinamika sejarah sosial perjalanan hukum saat itu lebih diwarnai oleh

21 de Ridha.

22 de Ridha. 
aturan sosial Islam dibandingkan aturan umum sehingga nilai-nilai keislaman berintegrasi dengan budaya masyarakat yang sudah ada dan ini dapat dilihat dari beberapa kasus penerapan hukum yang dapat ditelusuri dari aspek hukum Islam dan kearifan lokal masyarakat.

\section{Hukum Islam di Kalimantan Selatan Dewasa Ini}

Apabila (hukum) Islam menjadi sebuah aturan sosial di masa kerajaan, maka di masa setelahnya terjadi hal yang berbeda dengan tidak lagi menjadi sebuah aturan hukum yang positif. Hal ini terutama terjadi ketika Kerajaan Banjar sepenuhnya dikuasai oleh penjajah Belanda. Di bawah pemerintahan Hindia Belanda eksistensi hukum Islam mengalami pergeseran yang dinamis. ${ }^{23}$ Di awal kedatangan Belanda, eksistensi hukum Islam yang hidup di tengah masyarakat diakui sebagai hukum yang berlaku yang kemudian oleh ahli hukum Belanda Van den Berg disebut dengan teori receptio in complexu, dengan menyatakan bahwa hukum yang berlaku di Indonesia sesuai dengan agama yang dianut oleh para penduduknya. Akan tetapi, seiring dengan semakin kuatnya pertentangan terhadap kekuasaan Belanda, melahirkan sebuah kebijakan politik yang berupaya untuk melemahkan upaya penentangan tersebut. Hal ini menyadarkan penjajah bahwa keberadaan hukum Islam menjadi salah satu kekuatan perjuangan untuk melawan Belanda. Oleh karena itu, atas saran ahli hukum Belanda yang bernama Christiaan Snouck Hurgronje dan Cornelis Van Vollenhoven, maka pihak Belanda merubah kebijakannya dengan menetapkan bahwa hukum Islam berlaku jika telah diadopsi oleh hukum adat. Dalam teori hukum adat dikenal dengan sebutan teori receptie. ${ }^{24}$

Di bawah kekuasaan penjajah Belanda maka eksistensi lembaga hukum Islam (penghulu, qadi, ataupun mahkamah syar'iyyah) tidak lagi sebagaimana pada masa kerajaan, namun diletakkan di bawah sistem Pengadilan Umum yang dsiebut dengan Landraad. Hal ini berdampak kepada kewenangan pengadilan hukum Islam yang berada pada subordinasi dan putusannya harus mendapatkan persetujuan dari ketua Landraad. Di samping itu pula bahwa saat itu terjadi pemangkasan kewenangan (kompetensi) intstitusi peradilan hukum Islam dengan hanya terbatas pada bidang hukum keluarga. Pada tahun 1937 dikeluarkan Stbl. dengan nomor. 638 dan 639 yang menjadi dasar dibentuknya institusi untuk peradilan tingkat pertama yang disebut dengan Kerapatan Qadli dan peradilan untuk tingkat banding yang disebut dengan Kerapatan Qadli Besar di wilayah Kalimantan Selatan. Institusi ini

\footnotetext{
${ }^{23}$ Ahmad Azhar Basyir, "Hukum Islam Di Indonesia Dari Masa Ke Masa," Unisia 16 (1992). ${ }^{24}$ Basyir.
} 
mempunyai kewenangan yang sama dengan kewenangan yang terdapat pada Peradilan Agama untuk wilayah Jawa dan Madura. Berdasarkan Stbl. 1937 No. 116 disebutkan kewenangan tersebuta mencakup perselisihan suami isteri yang beragam Islam, persoalan nikah, talak, rujuk, dan perceraian yang memerlukan penanganan dari hakim agama Islam, pemberian putusan cerai, persoalan taklik talak, mahar dan nafkah isteri oleh suami... ${ }^{25}$ Dengan demikian, persoalan hukum Islam di luar apa yang telah disebutkan di atas menjadi kewenangan peradilan umum.

Eksistensi hukum Islam di wilayah Kalimantan Selatan sesungguhnya juga sama dengan apa yang terjadi di luar wilayah ini, terutama ketika Kalimantan Selatan tidak lagi sebagai sebuah kerajaan Banjar yang otonom, yang memiliki kekuasaan penuh atas politik dan hukum pada wilayahnya. Dengan berintegrasinya wilayah Kalimantan Selatan yang dulunya merupakan wilayah kekuasaan Kerajaan Banjar ke dalam Indonesia, maka kebijakan hukum pun mengikuti apa yang terjadi secara nasional, terutama yang terkait dengan politik hukum. Namun sebagai wilayah yang sangat kuat dengan tradisi keislamannya, maka tentu saja kesadaran terhadap hukum Islam oleh masyarakat Banjar tetap ada (eksis) walaupun tidak diterapkan secara formal dan institusional, terutama pada wilayah yang tidak menjadi kewenangan Peradilan Agama. Kesadaran akan hukum Islam yang ada di tengah-tengah kehidupan masyarakat inilah yang disebut dengan istilah the living law. Ini sebagaimana yang disebutkan oleh Rofiq bahwa hukum Islam Indonesia dapat dikategorikan menjadi dua bentuk yaitu pertama, hukum yang berlaku secara yuridis formal dalam bentuknya berupa hukum yang mengatur hubungan antar dan benda yang disebut hukum muamalat (perdata). Bagian pertama ini berupa positifisasi materi hukum ke dalam bentuk undang-undang, seperti perkawinan, kewarisan, dan perwakafan. Kedua, materi hukum dalam bentuk norma yang mengandung sanksi atau padanan kemasyarakatan. Ini bisa berupa ibadah murni atau hukum pidana. ${ }^{26}$

Keberlangsungan hukum Islam sebagai the living law, tidak akan pernah lepas dari peran para ulama. Sebagaimana yang telah disebutkan di atas, peran al-Banjari beserta para keturunan dan murid beliau begitu besar dalam menjadikan norma Islam sebagai sebuah nilai yang mewarnai sistem sosial

25 Dahlia Haliah Ma'u, "Eksistensi Hukum Islam Di Indonesia (Analisis Kontribusi Dan Pembaharuan Hukum Islam Pra Dan Pasca Kemerdekaan Republik Indonesia)," Jurnal Ilmiah Al-Syar'ah, 1, 15 (2017).

${ }^{26}$ Ahmad Rofiq, Hukum Islam Di Indonesia (Jakarta: Raja Grafindo Persada, 2000). 
budaya mereka. Secara umum sebelum al-Banjari, pengaruh yang kuat terhadap corak penerapan hukum Islam datang dari Jawa dan Aceh. Pada abad ke 16 Pengaruh Jawa terutama dari Demak dan Giri pada saat itu telah mewarnai paham dasar keagamaan masyarakat Banjar, yang dalam konteks fikih bercorakkan kepada mazhab Syafi'i. ${ }^{27}$ Hubungan kerajaan Banjar dengan Demak terkait dengan islamisasi kerajaan Banjar secara formal sebagaimana yang telah penulis sebutkan di atas. Sedangkan hubungan Banjar dengan Giri bisa ditelusuri dengan adanya catatan tentang adanya hubungan dagang yang terjadi di saat kerajaan Banjar belum berupa kerajaan Islam dan disebutkan bahwa Sunan Giri ketika aktif berdagang pernah menjadikan Kerajaan Banjar sebagai salah satu tujuan perdagangan, sehingga dimungkinkan terjadi sebuah islamisasi penduduk Banjar yang diikuti dengan paham keagamaan yang dibawa oleh para pembawanya.

Sedangkan pengaruh Aceh sangat besar dalam kurun waktu sekitar abad ke-17 yang dapat dilihat pada dua hal yaitu pertama bahwa salinan beberapa kitab yang diklaim sebagai kitab Barencong menyebutkan beberapa nama ulama Aceh yang hidup sekitar abad ke-16 dan 17 serta ada pula yang menyajikan karya-karya mereka. Istilah "barencong" sendiri dapat dihubungkan dengan kata rencong (senjata khas Aceh) atau tanah rencong (nama lain dari Aceh) walaupun cerita rakyat Banjar memaknainya sebagai kencong. Kedua, ada beberapa al-Banjari pada kitab Sabil al-Muhtadin yang menyebutkan bahwa dia banyak menemukan salinan-salinan naskah kitab Sirat al-Mustaqim karya alRaniri yang telah mengalami distorsi. ${ }^{28}$ Dua hal di atas cukup untuk menyebutkan bahwa ada pengaruh Aceh terhadap penerapan hukum Islam di masyarakat Banjar, terutama sebelum masa al-Banjari beserta para keturunan beliau.

Namun secara keseluruhan pengaruh al-Banjari beserta para keturunan beliau terhadap pelaksanaan hukum Islam di wilayah Kalimantan Selatan sampai sekarang menjadi hal yang lebih mendominasi melalui karyakarya yang dihasilkan oleh beliau beserta para keturunannya. Semenjak awal abad ke-19, para keturunan al-Banjari menyebar tidak hanya di Kalimantan Selatan saja, namun juga menyebar ke segenap Nusantara bahkan mancanegara dengan membawa serta karya al-Banjari beserta pemikirannya sehinga mendorong dinamisasi pemikiran hukum Islam di wilayah Kalimantan Selatan.

${ }^{27}$ Rahmadi, "Dinamika Intelektual Islam Di Kalimantan Selatan: Studi Genealogi, Referensi, Dan Produk Pemikiran,” Ilmu Ushuluddin 11, no. 1 (January 2012).

${ }^{28}$ Rahmadi. 
Hal ini berimpilkasi kepada lahirnya tipologi fikih yang berkembang semenjak eranya al-Banjari hingga dewasa ini. Rahmadi dkk dalam tulisannya menyebutka bahwa ada beberapa tipologi atau corak pemikiran fikih yang berkembang selama ini semenjak al-Banjari dan mempunyai pengaruh terhadap pemahaman hukum Islam di Kalimantan Selatan yaitu model fikih ibadah komparatif, model fikih praktis, model fikih sufistik, model fikih polemis, dan model kumpulan fatwa. ${ }^{29}$

Hukum Islam yang hidup di tengah masyarakat Banjar tentu saja mempunyai karekteristik tersendiri yang sesuai dengan kultur sosial, budaya dan ekologi setempat. Menjadikan fikih sebagai sebuah problem solving kehidupan masyarakat Banjar melahirkan corak pemikiran fikih yang kontekstual, tidak tekstual. Oleh karena itu, dalam kehidupan masyarakat Banjar, lahir konsep-konsep fikih yang berkarakter lokalistik sebagai bentuk respon terhadap perbedaan sosial budaya, dan lingkungan masyarakat Banjar dengan masyarakat Arab pada umumnya dimana fikih dirumuskan oleh para ulama terdahulu. Dalam konteks ini, al-Banjari bisa dikatakan sebagai pelopornya di wilayah Kalimantan Selatan. Karakter lokalistik terhadap konsep hukum dapat dilihat dari beberapa karya tulis yang telah beliau hasilkan dan menjadi kajian dan pegangan oleh masyarakat Banjar. Kitab Sabil al-Muhtadin misalkan, dalam beberapa aspek terlihat al-Banjari menekankan aspek fikih yang bekarakter lokalistik dalam menuangkan pemikirannya. Ini terlihat ketika ia memperluas apa yang sudah ada dalam kitab-kitab fikih yang menjadi rujukannya dengan konteks apa yang ada di daerah Banjar. Misalnya, di antara jenis makanan yang diharamkan adalah binatang yang mempunyai kemampuan hidup secara amphibi seperti katak, buaya dan sebagainya. Al-Banjari memasukkan ke dalam jenis ini binatang yang disebut kalambuai yaitu sejenis siput besar yang bisa hidup di air dan di darat dalam waktu yang lama. ${ }^{30}$ Contoh lainnya adalah menguburkan jenazah memakai tebala (keranda), hukumnya menjadi wajib jika tanahnya berair, sebagaimana banyak ditemukan di daerah ini. Padahal hukum aslinya adalah makruh lagi bid'ah. Contoh berikutnya adalah kasus harta perpantangan antara suami istri yang sama-sama bekerja. Menurut al-Banjari, harta perpantangan suami istri harus dibagi dua lebih dulu, bila salah satu di antaranya meninggal dunia karena dianggap sebagai harta

\footnotetext{
${ }^{29}$ Rahmadi, M. Husaini Abbas, and Abdul Wahid, Dinamika Dan Tipologi Pemikiran Taubid Fiqib Dan Tasawuf (Banjarmasin: IAIN Antasari Press, 2012).

${ }^{30}$ Rahmadi, Abbas, and Wahid.
} 
syirkah antara keduanya. Baru setelah itu harta warisan yang meninggal dibagi berdasarkan hukum faraid. ${ }^{31}$

\section{Simpulan}

Paparan yang telah diuraikan di atas hanyalah bagian kecil dari sebuah kajian hukum Islam di Kalimantan Selatan dari aspek kesejarahan, setting sosial politik, dan karakternya. Kajian yang lebih komprehensif tentu saja memerlukan telaahan yang lebih lama dan referensi yang lebih otoritatif dan banyak. Namun dengan demikian, paling tidak kita dapat mengetahui bagaimana perkembangan hukum Islam di tengah masyarakat Banjar yang identik dengan agama Islam beserta dinamikanya dari sejak berdirinya kerajaan Banjar sampai pada masa dewasa ini. Perkembangan hukum Islam yang terjadi ternyata mempunyai perjalanan sejarah panjang yang tidak lepas dari politik hukum, setting sosial dan intelektual di setiap periodenya. Satu catatan yang penting adalah bahwa ulama mempunyai peran yang signifikan terhadap perkembangan dan penerapan hukum Islam di wilayah ini. Sosok al-Banjari dengan inovasi hukum yang dirumuskan memberikan sebuah rintisan untuk mengembangkan sebuah produk hukum Islam yang lebih dinamis dengan karakter lokal sebagai unsur pembentuknya sehingga melahirkan sebuah terobosan fikih yang lebih kontekstual dengan situasi sosial, budaya dan lingkungan.(wallabu a'lam).

\section{Daftar Pustaka}

Azmi, Muhammad. "Islam Di Kalimantan Pada Abad Ke-15 Sampai Abad Ke -17." Yupa: Historical Studies Journal, 1, 1 (n.d.).

Basyir, Ahmad Azhar. "Hukum Islam Di Indonesia Dari Masa Ke Masa." Unisia 16 (1992).

Daud, Alfani. Islam Dan Masyarakat Banjar Diskripsi Dan Analisa Kebudayaan Banjar. Jakarta: Raja Grafindo Persada, 1997.

"Demografis Kalimantan Selatan," November 9, 2019. https://id.wikipedia.org/wiki/Kalimantan_Selatan.

Hakim, Arif Rahman. "Urang Banjar Asli, Urang Banjar Keturunan Dan Jarwo.” Idr UIN Antasari Banjarmasin, n.d. https://idr.uinantasari.ac.id/6268/.

Ma’u, Dahlia Haliah. "Eksistensi Hukum Islam Di Indonesia (Analisis Kontribusi Dan Pembaharuan Hukum Islam Pra Dan Pasca

${ }^{31}$ Rahmadi, Abbas, and Wahid. 
Kemerdekaan Republik Indonesia)." Jurnal Ilmiah Al-Syar'ah, 1, 15 (2017).

Mujiburrahman, Mujiburrrahman, Allfisyah Alfisyah, and Ahmad Syadzali.

"Badingsanak Banjar Dayak Indentitas Agama Dan Ekonomi Etnisitas

Di Kalimantan Selatan.” Riset Kaloborasi Program Knowlegde Based Pluralism CRCS UGM, n.d.

http://eprints.ulm.ac.id/219/2/14\%20Badingsanak\%20Banjar\%20Da yak.pdf.

Muzainah, Gusti. Asas Kemanfaatan Tentang Kedudukan Perempuan Dalam Hukum

Waris Adat Msyarakat Banjar. Yogyakarta: Pustaka Akademika, 2016.

Noor, Yusliani. "Sejarah Perkembangan Islam Di Banjarmasin Dan Peran

Kesultanan Banjar (Abad XV-XIX)." Al-Banjari, 1, 11 (2012).

Rahmadi. "Dinamika Intelektual Islam Di Kalimantan Selatan: Studi

Genealogi, Referensi, Dan Produk Pemikiran.” Imu Ushuluddin 11, no.

1 (January 2012).

Rahmadi, M. Husaini Abbas, and Abdul Wahid. Dinamika Dan Tipologi

Pemikiran Taubid Fiqib Dan Tasanuf. Banjarmasin: IAIN Antasari Press, 2012.

Ras, J.J. Hikayat Banjar: A Study in Malay Historiography. The Hague: Martius Najhoff, n.d.

Ridha, . Faqih de. "Potert Lain Perjalanan Hukum Di Kerajaan Banjar." Al-

Banjari 12, no. 1 (January 2013).

Rofiq, Ahmad. Hukum Islam Di Indonesia. Jakarta: Raja Grafindo Persada, 2000.

Saleh, Idwar. Sejarah Singkat Menegenai Bangkit Dan Berkembangnya Kota

Banjarmasin Serta Wilayab Sekitarannya Sampai Tabun 1950. Banjarmasin, 1975.

Sunarningsih, Sunarningsih. "Situs Jangkung Dan Komunitas Maanyan."

Naditira Widya, 2, 0 (Oktober 2016).

Syifa, and Nabila Saifin Nuha Nurul Haq. "Politik Hukum Islam Era

Kesultanan.” Jurnal Reflektika 13, no. 1 (June 2017).

Usman, Gazali. Urang Banjar Dalam Sejarah. Banjarmasin: Lambung Mangkurat

University Press, 1989.

Wardani. "Madam Ka Banua Urang Beberapa Catatan Awal Tentang Migrasi Suku Banjar, Proses Dan Peyebarannya." Jurnal Kebudayaan Kandil V, no. 14 (Oktober 2007). 